\title{
Front Matter: Volume 11896
}

, "Front Matter: Volume 11896," Proc. SPIE 11896, Advanced Optical Imaging Technologies IV, 1189601 (28 October 2021); doi: 10.1117/12.2619253

SPIE. Event: SPIE/COS Photonics Asia, 2021, Nantong, Jiangsu, China 


\title{
PROCEEDINGS OF SPIE
}

\section{Advanced Optical Imaging Technologies IV}

\author{
Xiao-Cong Yuan \\ P. Scott Carney \\ Kebin Shi \\ Editors
}

\section{0-11 October 2021 \\ Nantong, China}

Sponsored by

SPIE

COS-Chinese Optical Society

Cooperating Organizations

Tsinghua University (China) - Peking University (China) - University of Science and Technology of China (China) - Zhejiang University (China) - Tianjin University (China) Beijing Institute of Technology (China) - Beijing University of Posts and Telecommunications (China) • Nankai University (China) • Changchun University of Science and Technology (China) - University of Shanghai for Science and Technology (China) - Capital Normal University (China) - Huazhong University of Science and Technology (China) - Beijing Jiaotong University (China) - China Jiliang University (China) • Shanghai Institute of Optics and Fine Mechanics, CAS (China) - Changchun Institute of Optics, Fine Mechanics and Physics, CAS (China) - Institute of Semiconductors, CAS (China) • Institute of Optics and Electronics, CAS (China) - Institute of Physics, CAS (China) - Shanghai Institute of Technical Physics, CAS (China) - China Instrument and Control Society (China) - Japan Optical Society (Japan) - Optical Society of Korea (Korea, Republic of) - Australia and New Zealand Optical Society (Australia) - Optics and Photonics Society of Singapore (Singapore) - European Optical Society

\section{Supporting Organizations}

China Association for Science and Technology (CAST) (China) - Department of Information of National Nature Science Foundation, China (NSFC) (China)

Published by

SPIE

Volume 11896 
The papers in this volume were part of the technical conference cited on the cover and title page. Papers were selected and subject to review by the editors and conference program committee. Some conference presentations may not be available for publication. Additional papers and presentation recordings may be available online in the SPIE Digital Library at SPIEDigitalLibrary.org.

The papers reflect the work and thoughts of the authors and are published herein as submitted. The publisher is not responsible for the validity of the information or for any outcomes resulting from reliance thereon.

Please use the following format to cite material from these proceedings:

Author(s), "Title of Paper," in Advanced Optical Imaging Technologies IV, edited by Xiao-Cong Yuan, P. Scott Carney, Kebin Shi, Proc. of SPIE 11896, Seven-digit Article CID Number (DD/MM/YYYY); (DOI URL).

ISSN: 0277-786X

ISSN: 1996-756X (electronic)

ISBN: 9781510646414

ISBN: 9781510646421 (electronic)

Published by

SPIE

P.O. Box 10, Bellingham, Washington 98227-0010 USA

Telephone +1 3606763290 (Pacific Time)

SPIE.org

Copyright @ 2021 Society of Photo-Optical Instrumentation Engineers (SPIE).

Copying of material in this book for internal or personal use, or for the internal or personal use of specific clients, beyond the fair use provisions granted by the U.S. Copyright Law is authorized by SPIE subject to payment of fees. To obtain permission to use and share articles in this volume, visit Copyright Clearance Center at copyright.com. Other copying for republication, resale, advertising or promotion, or any form of systematic or multiple reproduction of any material in this book is prohibited except with permission in writing from the publisher.

Printed in the United States of America by Curran Associates, Inc., under license from SPIE.

Publication of record for individual papers is online in the SPIE Digital Library.

\section{SPIE. DIGITAL}

Paper Numbering: A unique citation identifier (CID) number is assigned to each article in the Proceedings of SPIE at the time of publication. Utilization of CIDs allows articles to be fully citable as soon as they are published online, and connects the same identifier to all online and print versions of the publication. SPIE uses a seven-digit CID article numbering system structured as follows:

- The first five digits correspond to the SPIE volume number.

- The last two digits indicate publication order within the volume using a Base 36 numbering system employing both numerals and letters. These two-number sets start with 00, 01, 02, 03, 04, 05, 06, 07, 08, 09, 0A, OB ... 0Z, followed by 10-1Z, 20-2Z, etc. The CID Number appears on each page of the manuscript. 


\section{Contents}

NOVEL IMAGING TECHNOLOGIES

11896 OK Quantitative phase imaging with mixed-transfer-function for resolution enhancement [11896-19]

$118960 \mathrm{M}$ Optofluidic varifocal lens actuated by dielectric elastomer sandwiched by two conductive liquids with different refractive indexes [11896-21]

11896 ON Snapshot ghost diffraction imaging based on spatial averaging [11896-22]

\section{POSTER SESSION}

1189600 Effects of substrate stiffness on the mechanical characteristics of breast cells using atomic force microscopy [11896-23]

11896 OP Solutions on high-resolution multiple configurations [1 1896-24]

$11896 \mathrm{OQ} 2 \mathrm{2}$ sizing measuring system of regular particles by semi-automatic image analysis technique [11896-25]

11896 OU Depth resolution enhancement using light field light sheet fluorescence microscopy [1 1896-29]

11896 OV The measurability analysis of abnormality detection based on DOT method using stack auto-encoding neural network model [1 1896-30]

11896 OY Effective frequency band and signal extraction of dynamic Stokes vector measurements [11896-33]

1189615 An improved phase measuring deflectometry method for defect detection of specular reflection surface [11896-40]

1189617 Infrared image super-resolution reconstruction based on closed-loop regression network [11896-42]

1189618 A visible light photon-counting imaging detector based on induction readout [1 1896-43]

118961 A Tilt and displacement correction for digital holographic multi-aperture imaging [1 1896-45]

11896 1B Two-step spatial-temporal compressive sensing imaging [11896-46] 
11896 1C Dual-camera phase retrieval based on fast adaption image restoration and transport of intensity equation [1 1896-47]

Proc. of SPIE Vol. 11896 1189601-4

Downloaded From: https://www.spiedigitallibrary.org/conference-proceedings-of-spie on 26 Apr 2023 Terms of Use: https://www.spiedigitallibrary.org/terms-of-use 